\title{
The Story of a Street - (mis)tackling social exclusion in public policy
}

\author{
Tereza Grosse ${ }^{1 凶}-$ Peter Brnula $^{1}-$ Jitka Laštovková $^{1}-$ Jan Vašat $^{1}-$ \\ Alexandra Petrů 1 \\ ${ }^{1}$ Faculty of Social and Economic Studies, J. E. Purkyně University in Ústí nad Labem, Ústí nad Labem, Czechia \\ $\bowtie$ tereza.grosse@seznam.cz
}

\begin{abstract}
Spatial exclusion as a result of social exclusion is a complex problem that hinders the development of territories and undermines social cohesion in society. These are issues that need to be addressed at a local level through cooperation between the various influential bodies (public administration, politicians, citizens, social workers, the media among others). This article examines social exclusion based on an internationally recognised case that occurred in the Czech Republic 10 years after the 1989 democratic revolution. The starting point for this article is 1999, when a chain of decisions made by public administration resulted in the emerging spatial segregation in Matiční Street in the region's capital Ústí nad Labem. The article is based on semi-structured oral history interviews with social participants. It identifies barriers for the successful resolution of issues at that time on the basis of the Pierson theory of social exclusion (2010) as the insufficient use of local participation and networks and their abuse for political and media purposes. Using the lens of social actors, it is looking for important milestones and lessons learned for the future development in public policies.
\end{abstract}

\section{Keywords}

Social exclusion, Spatial segregation, Matiční street, Public administration, Local development

Received: 27 May 2020

Received in revised form: 11 December 2020

Accepted:

13 December 2020

\section{Highlights for public administration, management and planning:}

- Social exclusion is posing a problem in the Czech Republic since 1990s, resulting in a serious barrier to the growth of opportunities within the region.

- Social cohesion in society is undermined as a result of mistreatment due to social exclusion, especially in regions with limited resources.

- Regional planners can learn from past examples where social exclusion was specifically addressed in a region or locality (e.g. the case study of Matiční Street which may be applied to the Ústí nad Labem region).

- Public administration is not able (or not willing) to react locally and with flexibility and cooperation when social problems arise.

\section{Introduction}

Social exclusion in the Czech Republic has been a topic of social and interdisciplinary discussion since the last decade of the $20^{\text {th }}$ century due to the sudden and unexpected social issues that followed the Velvet Revolution which expanded the territory of socially excluded localities. The regions facing the consequences of structural change are more often exposed to this problem just as in the case of the Ústí region (Koutský 2012). Despite the governmental and non-governmental efforts to address social exclusion through various national and locally-focused programmes and interventions, the empirical evidence from many cities suggests the ambiguous success of the public policy (Mareš 2006; Sýkora 2018). For this reason, more long-term research and re-evaluations of the policies are needed to identify the policy gaps.

The following article explores an internationally known case of social exclusion on Matiční Street in Ústí nad Labem (e.g., Furlong 1999; Wilson 2012). It identifies the controlled spatial segregation of the Roma, which took place twenty years ago and has become an internationally known case that is symptomatic and worth studying. The aim of this research is to understand how 
results of the Matiční street case are perceived twenty years later on the basis of interviews with the events' participants. In particular, it explores what factors can now be interpreted as key factors of a failure or a success of the public policy? We draw attention to the mistakes of various public organisations and private citizens that in similar situations could disturb social cohesion today.

\section{Social Exclusion in a Geographical Context}

The concept of social exclusion is multidimensional and can be described as a set of factors that affect people's lives in places where there is a higher concentration of disadvantaged people. It extends the concept of poverty in ways other than economical attributes; poverty means vertical inequalities, exclusion horizontal. Social exclusion persists in time and space, and is associated with marginalization and pathological behaviour, rejection of norms, dependence on the welfare state and the disintegration of traditional institutions. The concept began to be used in the 1970s in social sciences and in the Czech context for analysis of newly establishing social reality in the late 1990s (e.g. Mareš 2000).

The most visible dimension is spatial exclusion: socially excluded localities. They are characterized by high unemployment rate, lower quality of housing, higher crime rate, low qualifications, lower level of education, services including medical care, etc. This accumulation of socio-economic disparities results in disruption of social cohesion, and a high financial burden on the state. It inhibits local development, and also plays an important political role in public policy planning and as a political issue (Bernard \& Simon, 2017). According to Pierson (2010), the demarcation of social exclusion is ambiguous and it is possible to look at the problem from many different perspectives (political, the individuals, the neighbours, etc.). In general, however, it is a process that makes it difficult for certain individuals and social groups to access society's resources (economic, cultural, social, political, etc.). Pierson (2010) considers the signs of social exclusion as; poverty and low incomes; lack of access to the labour market; a minimal or non-existent social safety net and social network; the type of neighbourhood and exclusion from services. Additionally, Mareš (2008) considers not only the concentration of people at risk, but also environmental factors such as poor housing, high unemployment, poor transport accessibility, infrastructure, and crime as grounds for the creation of an excluded location. Poor planning or neglect may also lead to crime within the community. At a state level, Lichter (2015) affirms that infrastructure, civic amenities, housing quality, and institutional conditions can influence the situation, but that ultimate responsibility lies with local participants. According to Lux (2003), apart from these typical kinds of social exclusion, there is also the influence of human capital and the residential environment. Macešková (2009), also includes environmental and institutional conditions. Life in an environmental context includes the relation of inhabitants to the location and how people perceive it from the outside.

Levitas (2005) describes three approaches as causes of social exclusion. The first is redistributive, taking into account the unequal distribution of income in society and can be eliminated through redistribution. However, this approach cannot be influenced by individuals who are in a position of social exclusion. The second approach reflects a moral view that points to pathological behaviour caused by the failure of individuals. The third socially integrative approach is based on the employment of the individual, which should unify society through participation in the labour market.

As emphasized by Pierson (2010), when dealing with cases of social exclusion, especially socially excluded localities, it is crucial to introduce various aspects of a participatory approach. A multidisciplinary and community approaches form the basic principles on which it is necessary to build.

He characterizes five basic "building blocks" needed to eliminate social exclusion. These include relevant information on available resources for socially excluded, strengthening social support and networks, partnering with local organizations, creating platforms for possible effective participation of disadvantaged neighbourhoods and focusing on the locality as a whole and community practice (Pierson 2010).

According to Jenkins (2014) fundamental aspect of combating social exclusion is the principle of creating collective identities using the categories "we" and "they". It is stressed that without "they" we would not be "we". Therefore it is not so important how "we" define ourselves, rather what "we" attribute to them (e.g. signs of social exclusion, Roma ethnicity in our case study). Creating ingroups and out-groups is an anthropological constant (Lévi-Strauss 1963), and otherness is the key category for building identity. Members of outgroups are characterized by lack of identity and often also humanity, based upon stigmatizing and sim- 
plistic stereotypes. Not only in this context, but typically in Western civilisation, 'in'-groups mean civilisation, order and development, whilst the others signify the opposite. The main idea here is the creation of imaginary categories to which we attribute different characteristics and so we think of people, not as separate human beings, but as members of certain categories that we create. According to Jenkins (2014), ethnic categories are attributed externally as opposed to ethnic groups that are voluntarily accepted identities. Segregation is the result and evidence - as Stazsak (2009) states, the ghetto creates otherness.

Social exclusion includes all of the problems listed above, but public administration often perceives social exclusion as simply the so-called "socially excluded localities", which are formed as a result of placing a minority group in one location. Environmental issues are viewed by public administration simply as a problem that needs to be addressed only in that particular place.

In socially excluded localities, there is a higher concentration of such disadvantaged persons, who are represented in the Czech environment mainly by the minority Roma ethnic group. The ethnic identity of socially excluded parties and the collective identity of all social parties, in general, become an important element in our story. The phenomenon of exclusion also appears in the strategic documents for social integration of Roma population in the Czech Republic (Czech Republic 2015). According to Lichter (2015), the phenomenon of socially excluded localities is not restricted to big cities, quite the contrary. This has already been confirmed by Czech authors (Musil 2004; Musil \& Müller 2008; Ouředníček 2006; Ouředníček et al. 2009a), who studied the problem meticulously, looking at municipalities, neighbourhoods, streets, even down to specific houses (Čada 2015). This research states that in the Ústí nad Labem Region the number of socially excluded localities increased from 63 to 89 between 2006 and 2014. The Ústí nad Labem Region was at the top of the list along with the Moravian-Silesian Region in absolute numbers. We are talking about an increase of approximately 8200 people (Čada 2015). Current figures are not available, but the change in this area is very dramatic.

Sýkora's important research from 2018 (Sýkora 2018) deals with other towns and not only Ústí nad Labem similarly with specific neighbourhoods, identifying risk areas where it is not appropriate to concentrate people at risk of social exclusion. In Ústí nad Labem, 16 basic settlement units are identified, with an extremely high or high percentage of excluded people and another 30 basic settlement units, where it is not recommended to increase the number of socially excluded population by more than 50. This text refers to the root of this situation dating back to the 1990s.

\section{Case study area - A History of Matiční Street}

In this section, we present a brief overview of the analysed events: the plan of municipal authorities to build a wall in the middle of Matiční Street in Ústí nad Labem so as to separate apartment buildings inhabited by Roma and socially disadvantaged residents from family houses inhabited by the majority. In 1994, the Roma people were moved into apartment buildings (loggias) on Matiční Street. The ethnic category perspective of the time by Jenkins was applied during occupancy, for which the Roma acquired flats for various reasons (Rmosty 1999). The only thing that connected them all was the "Rom" category, used by the competent authorities to allocate the apartments. Based on this ethnic category, a possible unintentionally segregated site was created here. This change in the concentration of disadvantaged people was also apparent to the people already living in the neighbourhood in family homes.

Up until 1997 there were ongoing disputes between the majority who lived in family houses and the minority who lived in apartment buildings (Fig. 1). These problems were recorded by the local town hall who proposed the construction of a wall between the neighbours to resolve the situation. The former Mayor of Ústí nad Labem supported the construction of the wall, the President of the Czech Republic Václav Havel was strongly against it and preferred other solutions. To support these other solutions, he commissioned a professional sociological analysis of the situation (used in the resources: R-mosty 1999). Addressing the Mayor of Ústí nad Labem, the then president Havel said: 'He speaks for his constituents and apparently believes that it is his duty to share all the prejudices, including racial, that the citizens of this city have.' (Roček 1999). At that time, the Czech Republic was negotiating to join the EU, and this case soon gained an international political dimension. There was a risk that if a wall was built it would be a reason to not accept the Czech Republic into the EU. On 8 November 1999, in Matiční Street, European Commissioner Günter Verheugen said: 'This wall has no place in today's Europe. Po- 


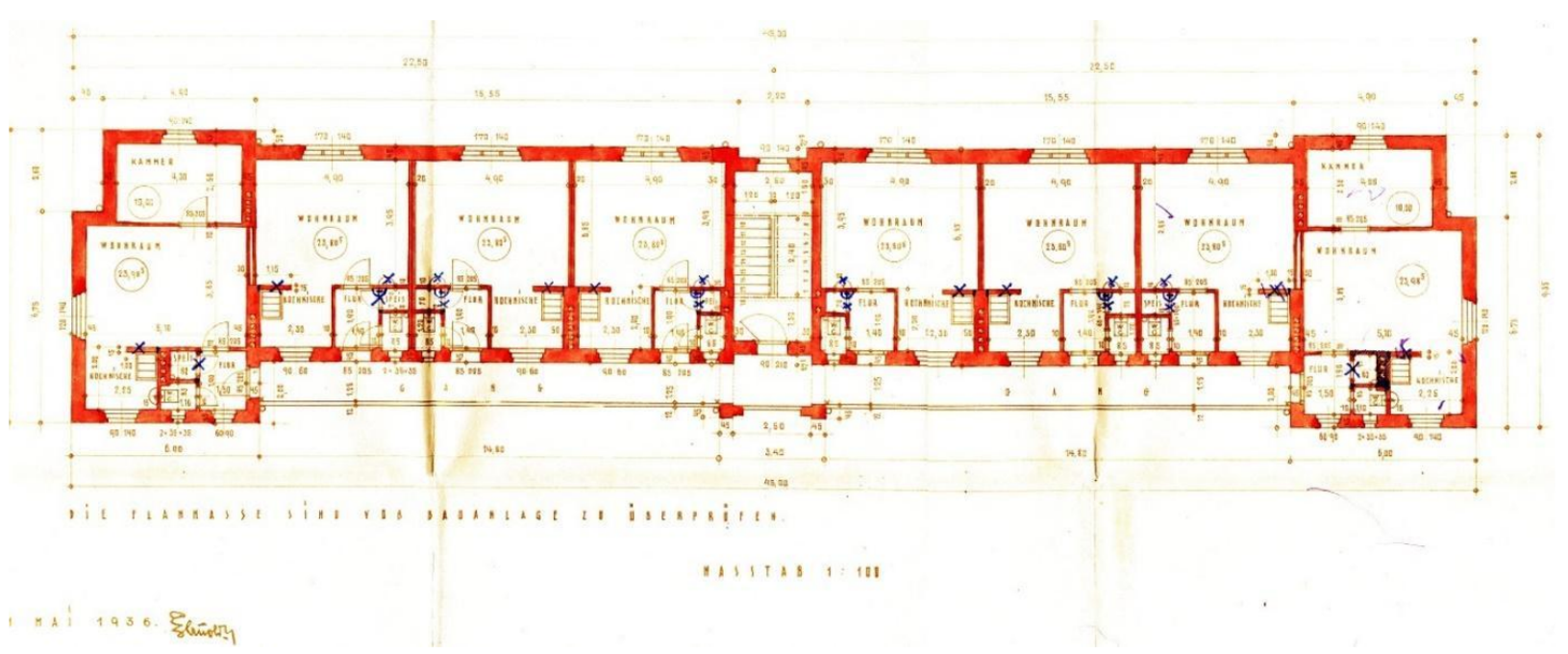

Fig. 1 Apartment buildings - plan. Source: Archive of Ústí nad Labem.

litically, the decision of the Ústí Council has created an image of the Czech Republic that is very harmful.' (Roček 1999). At the same time, disputes in the neighbourhood were exacerbated by media pressure and public interest.

The city of Ústí nad Labem decided in April 1998 to build a wall, a month later the government forbade it. In autumn 1998 the wall was finally built. Supported by human rights activists, local Roma people were in opposition and wanted the wall demolished. Following pressure from the EU the government dismantled the wall a month later even though a compromise had been reached between the locals (the wall with more gates and a playground) and that building the wall could be restarted with the consent of the locals. This was not taken into account from the outside. On a political level the options were either yes to a wall yes or no.

As early as 1998, President Havel declared the need to address the causes of the social problem. However, the government eventually purchased the buildings on the other side of the street from the majority who owned the family houses - eliminating the majority of the problem (irreversibly giving the public a signal of their attitude), and leaving the segregated location on its own. Without a sufficient solution and without a wall. There was no one to separate from.

\section{Methodology}

The research is based on a qualitative paradigm so it can work with the different points of view of those involved. The method of semi-structured interviews supplemented was chosen as a data collection technique. Altogether, 13 interviews were conducted with various people involved (shown in table 1): local people - minority and majority people (LP), journalists (J), municipal police (MP), human rights activists (RA), social workers (SW), city and district representatives (DR), and independent experts (E). The number of narrators in the neighbourhood as well as in society as a whole has been limited due to the fact that some of those involved have already died or moved and could not be traced. The aim of the selection of narrators was to form a snowball reaction and to obtain the widest possible spectrum of opinions and views. Unfortunately, locals expressed their attitude by rejection or silence rather than expressing views in the interview. The interviews were oriented towards a defined historical event and its consequences, so the technique can be described as semi-structured oral historical interviews (Vaněk 2015). Interviews were conducted at a place specified by the narrator, ranging from 20 minutes to 90 minutes between May 2018 and May 2019. Interviews were recorded and subsequently written down. Some of the participants refused to give their consent to the recording, in which case only notes were made or in some situations, replies were received in writing. The narrators were instructed about the purpose of the interview and the possibility of refusing to answer, all of them gave their consent to the interview. One of the narrators wished not to be anonymous. 
Table 1 List of narrators

\begin{tabular}{llll}
\hline Signification & Role & Perspective & M/F \\
\hline LP 1 & Local people (residents of family houses) & Majority & $\mathrm{F}$ \\
LP 2 & Local people (residents of loggias) & Roma & $\mathrm{M}$ \\
LP 3 & Local people (residents of loggias) & Roma & $\mathrm{M}$ \\
J 1 & Journalist & Local journalist & $\mathrm{M}$ \\
MP 1 & The Municipal Police & Patrolman in district & $\mathrm{M}$ \\
MP 2 & The Municipal Police & Patrolman in district & $\mathrm{M}$ \\
RA 1 & Human rights activists & National government agency & $\mathrm{M}$ \\
DR 1 & Representatives of the city and city district & Representatives of public administration (city district) & $\mathrm{F}$ \\
DR 2 & Representatives of the city and city district & Representatives of public administration (city) & $\mathrm{F}$ \\
E 1 & Independent experts & Lawyer & $\mathrm{F}$ \\
E 2 & Independent experts & Historian & M \\
E 3 & Independent experts & Researcher & $\mathrm{M}$ \\
SW 1 & Social worker & Community worker & $\mathrm{M}$ \\
Overall 13 & & & \\
\hline
\end{tabular}

Source: own processing

The analysis of interviews was based on an interpretative paradigm. The interviews were analyzed using codes and categories within the thematic content analysis. Some categories were found in all interviews across groups of respondents, others were typical only for some. In the following text, we work with the identified core categories and codes.

\section{The Matiční Street Case 20 Years Later Through the Eyes of its Participants}

The situation in Matiční Street arose by moving people with the same ethnic category and accumulated various disadvantages into one space. Research by Socioklub (2003: 17) summarizes the reasons for moving individual households, but doesn't include a transparent selection of tenants who were relocated to Matiční street. The Roma ethnicity was the only connecting element. This fact, based on stereotypes common in Czech Republic society, led to the conviction that these people were not competent living in houses. This prompted segregation of the inhabitants into apartment buildings on Matiční Street. Some narrators add that similar activities in other cities had been forgotten, despite being a common strategy. Narrators including activists and social workers similarly claim what one public official summarizes: '...and we behave as if excluded localities are created only by accident... Often this was not so.' (E 1).

\subsection{Jenkins' story of us and them}

The signs of an excluded locality (including social risk phenomena) appeared on Matiční street between 1994 and 1997. Problems escalated in coexistence with the majority group who lived in family homes. First, the mayor of the district, and then the city mayor, made a proposal to the majority to build a wall, without attempting a dialogue between the two groups.

One of the things that narrators identified as creating conflict was their view that the municipality mismanaged public space and did not allow children to move freely in this environment other than between houses. One of the narrators summarized the physical environment at that time as follows: 'There is rubble here, rubble there, a railroad here, a neglected pedestrian tunnel there, a railroad here, a highway here and where can the children play?' (SW 1).

\subsection{Media and political issues -the lost interests}

Another important point in this case is the role of the media through the eyes of those involved. For the first time, society and the media were intensely engaged in social exclusion in the Czech Republic. The media coverage was so overwhelming and successful that the information gained international interest. At that time, according to narrators, local politicians were not prepared to deal with the media. Many mistakes were made that strengthened stereotypes in society and impeded a longterm appropriate solution which required a wellchosen, shared approach to social exclusion in the 


\section{sciendo}

city. Moreover, the media's interest and pressure did not help residents who had to work together. In addition, whilst negotiating the solution of a wall on Matiční Street, local elections were held that made the wall a political issue. This is confirmed by quotes from a Police Officer and a Social Worker who share this view. 'I say this frankly, the political interest was only because politicians wanted to benefit personally from it. And that's why the city council never played any positive role.' (SW1). 'It was basically just a way for somebody to get into power, and I think that's what it was. It was nothing else.' (MP 1).

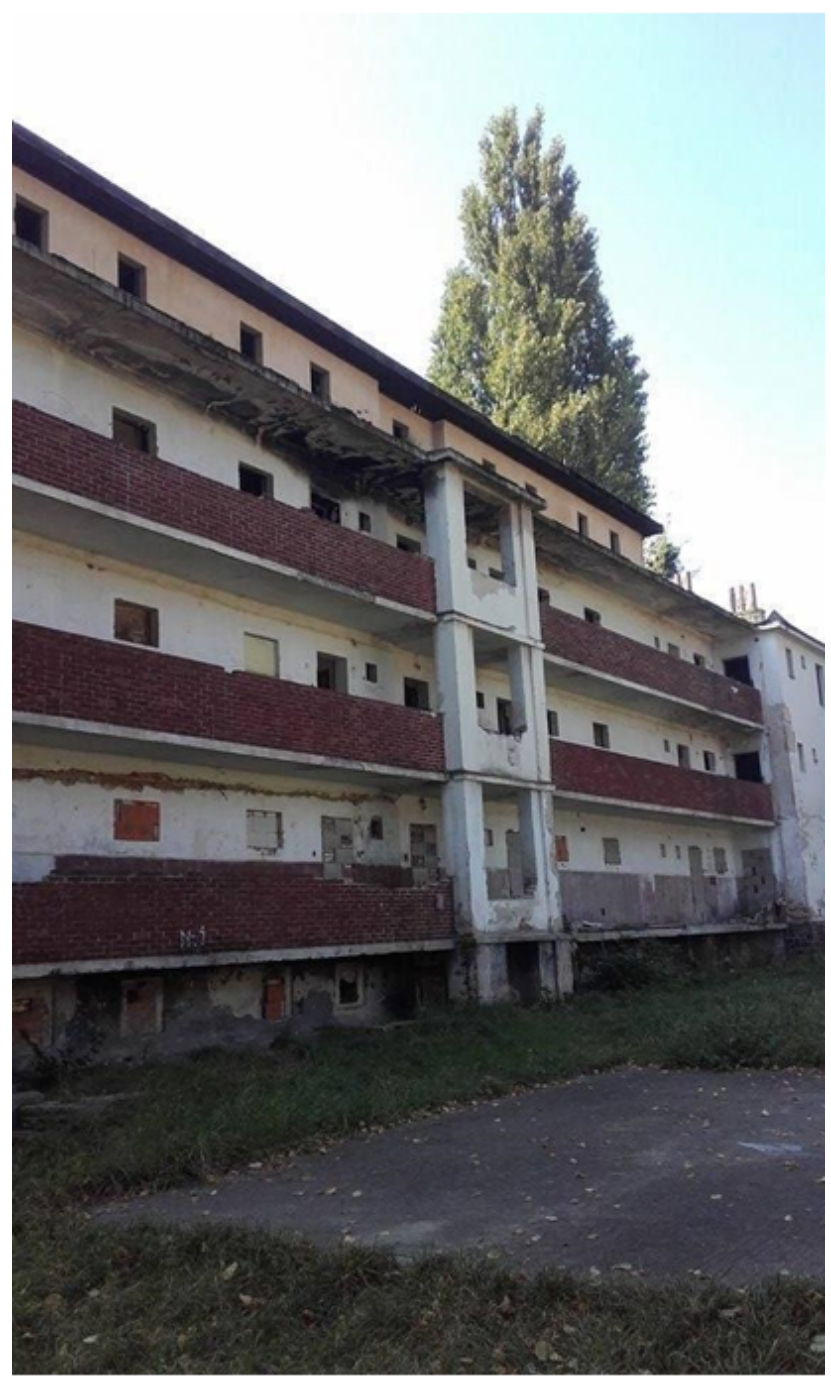

Fig. 2 Apartment buildings - current state. Source: Tereza Grosse, 2019

\subsection{Lost chance for participatory approach and building community}

The unfortunate interplay of events because of the wall on Matiční Street together with the media coverage influenced the international position on the entry of the Czech Republic to the EU. The primary and more important interest was the future of the Czech Republic. However, locals wanted to solve local problems and they did not see any added value in EU interest. On the other hand society scapegoated the Roma people, seeing them as its enemy and the origin of all the problems. (Socioklub 2003). One of the narrators said of the situation: 'After the revolution, all citizens were decimated and angry, so they thought it was necessary to deal with this' (DR 1). All this occurred without the preventive intervention of social workers and without deeper, active and thoughtful action by the public administration. Despite this, narrators reached a peaceful agreement with the help of social workers: '...a meeting was held in a house owned by a majority resident. Roma people were present along with owners of the original houses. A mediator was also invited... (the results were ignored by the town hall and also by the social departments)' (SW 1). According to one of the narrators, local government missed a unique opportunity to resolve the situation peacefully with a common agreement between the inhabitants. The locals were paid off and after some time even the apartment buildings were left empty (shown in figure 2) and '... then it was all forgotten.' (LP2).

\section{Discussion and conclusion}

The conclusion of this research is based on the subjective insights of witnesses who, after many years, different roles and life experiences, evaluate the situation retrospectively from a present-day point of view. Primarily though, it captures a specific moment. The dynamics of development, typical in the emergence and extinction of urban socially excluded localities, and the absence of media interest for such topics make it largely impossible to collect comparable data.

The aim of the research was to find out how the actors of the 20-year-old events in Matiční Street perceive the events from today's perspective. Narrators from all the groups agreed that the essence was rather political interests and media sensations. They mentioned the lost chance for constructive participatory solutions, 
promising and untapped community involvement and muted prospects for the future.

Wilson (2012) identifies Matiční Street as a classic example. In this environment a naturally socially excluded locality could have arisen due to changes in economy and use within a city, but the authorities purposefully moved disadvantaged residents to this place and concentrated the problem. The only common feature of the people who were then moved into the location was ethnicity. This created a dichotomous environment with confrontation. The resolution was dependent on the government of the Czech Republic who found a solution without addressing the causes. Narrators mainly agree that the Matiční case and its media coverage permanently damaged the face of the city and divided its society. This is a critical point for the further development of the city.

This example confirms that some of the five points for tackling social exclusion mentioned by Pierson (2010) were not fundamentally fulfilled in the Matiční case. Local organizations, who were required to co-operate and work in partnership, did not take into account the joint opinions of politicians and all of the residents of Matiční, despite the fact that communication in the neighbourhood was set up thanks to the support of social workers and community work. Consequently, a platform for effective participation was created by Pierson, but it was produced on an ad-hoc basis and was not used effectively. On the contrary, it was somewhat overlooked by decision-making institutions. Thus, it is not possible to talk about successful fulfilment at this point, and the narrators speak of disappointment at their unfulfilled efforts.

Pierson (2010) also focuses on the final efforts within the neighbourhood. In this respect, public administration did not take any of the possible approaches. They could have worked towards the integration of the socially disadvantaged minority groups and created a new local community, but they prevented this by moving the natives from their family homes. Additionally, the second liberal approach may have been to try to be inclusive, but even here mistakes were made by separating the inhabitants by building a wall, thus causing infighting and finger pointing leading to the strengthening of differences and stereotypes in a heterogeneous group. Working with such a group is not easy, but the proper use of professional social workers to solve community problems (mediation of disputes in the neighbourhood, public space planning) and the preference of community solutions over political self-presentation could have played an important role. At present it is not possible for Ústí nad
Labem to deny the social problems within the city. On the contrary, city officials still use the same approach to social exclusion and its causes as in the Matiční Street case. This is a moral view (Levitas 2005) that points to pathological behaviour caused by individual failure and not by the environment. In the socially disadvantaged area, this is a strong political issue (segregationist attitudes towards minorities), which applies to all citizens, and in elections this strategy and outlook is reinforced by the votes of the electorate.

The Matiční case provides a practical lesson for public administration in that it is necessary to avoid categorization within the stated group, transparency is key for the future development of social capital and trust in institutions. It is also vital to think about the observed consequences of the past without exception, and ideally, the view reflected by the state of Václav Havel, that the causes need to be addressed. In Ústí nad Labem, trust in the institution and relations between the inhabitants were irreversibly disturbed by the Matiční case and further deepened by local policies. As one of the narrators stated, it is impossible to pretend that other socially excluded localities were created by chance. And today? At present, the Ústí nad Labem Region is the region with the largest number of socially excluded localities with the largest share of the population living in the conditions of these localities (Čada 2015). In the city of Ústí nad Labem itself, we can find almost 50 places that can be described as socially excluded or endangered by social exclusion (Sýkora 2018).

In the Europe 2020 strategy document, The Czech Republic has committed itself to reducing levels of poverty and social exclusion. This document clearly defines terms, assesses the situation in the Czech Republic and provides a framework for drawing on European Structural and Investment Funds. The European Union's main objective is, above all, social and economic cohesion, which can be affected by spatial inequality and differentiation. In this respect, the presented research outlined possible methodological approaches and identified specific public policy gaps that provide impetus for further focus on the prevention of social exclusion. 


\section{Acknowledgements}

This project was financed by student grants, „The Wall in Matiční" with number: UJEP-SGS-2018-45.

\section{References}

Bernard J, Šimon M (2017) Vnitřní periferie v Česku: Multidimenzionalita sociálního vyloučení ve venkovských oblastech [Inner Peripheries in the Czech Republic: The Multidimensional Nature of Social Exclusion in Rural Areas]. Sociologický časopis / Czech Sociological Review 53: 3-28.

Czech republic (2015) Strategie romské integrace do roku 2020 [Roma integration strategy until 2020]. Úřad vlády ČR, Praha.

Čada K (ed.) (2015) Analýza sociálně vyloučených lokalit v ČR(Analysis of socially excluded localities in the ČR). GAC spol. s.r.o., Praha.

Furlong R (1999) Czechs pull down Gypsy wall. BBC (November 24, 1999). Available at: <http://news.bbc.co.uk/2/hi/europe/534383.stm>

Jenkins R (2014) Social Identity. Routledge, London.

Koutský J. et al. (2012) Economic and Social Trends of the Development in the Ústí nad Labem Region after 1989 [in Czech]. J. E. Purkyně University, Ústí and Labem.

Lévi-Strauss C (1963) Structural antropology. Basic Books, Inc., New York. MacMillan, Basingstoke.

Lichter D (2015) Toward a New Macro Segregation? Decomposing Segregation within and between Metropolitan Cities and Suburbs. American Sociological Review, 80: 843-873.

Lux M (2003) Housing policy: an end or a new beginning?. Local Government and Public Services Reform Initiative, Budapest.

Macešková M, Ouředník M, Temelová J (2009) Sociálně prostorová diferenciace v České republice: implikace pro veřejnou (regionální) politiku [Socio-spatial differentiation in the Czech Republic: implications for public (regional) policy]. Journal of Economics 57: 700-715.

Mareš P (2008) Sociální vyloučení (exkluze) a sociální začleňování (inkluze): koncepty, diskurz a agenda [Social exclusion and social inclusion: concepts, discourse and agenda]. Sociologický časopis, 44: 271-294

Majerová V, Kostelecký T, Sýkora, L (2011) Sociální kapitál a rozvoj regionu: př́klad Kraje Vysočina (Social Capital and Regional Development). Grada, Praha.
Musil J (2006) Regionální a místní formy sociálního vyloučení a jak jim čelit - problem vnitřních periferií v České republice [Regional and local forms of social exclusion and how to face them - the problem of internal peripheries in the Czech Republic]. In: Sirovátka T (ed) Sociální vyloučení a sociální politika [Social exclusion and social politics]. Masarykova univerzita, Brno.

Musil J, Bayer I, Jeřábek H, Mareš P, Prudký L, Sedláčková M, Sirovátka T, Šafr J (2004) Pojetí sociální soudržnosti v soudobé sociologii a politologii [Insurance of Social Cohesion in Contemporary Sociology and Political Science]. CESES, Praha.

Ouředníček M (2006) Sociální geografie Pražského městského regionu [Social geography of the Prague city region]. Charles University, Praha.

Ouředníček M, Temelová J, Puldová P, Novák J (2009) Metody geografického výzkumu města (Methods of geographical research of the city). In: Ferenčuhová S (ed) Město: proměnlivá ne/samozrejmost [City: variable no/obvious]. Mervart, Brno, pp. 93-125.

Pierson J (2010) Tackling social exclusion. Routledge, London.

R-mosty (1999) Analýza vzniku, aktuální situace a možností řešení problémů obyvatel Matiční ulice [Analysis of occurrence, current situation and possibilities of solving problems of inhabitants of Matiční street]. Socioklub, Praha.

Roček F (1999) Zed': Matiční - dokument o nejslavnější uličce světa [Wall: Matiční - a documentary about the most famous alley in the world]. Muzeum města Ústí nad Labem, Ústí nad Labem.

Socioklub (2003) Srovnávací studie o vývoji sociální situace rodin v Matiční ulici v městské části Neštěmice v Ústí and Labem [Comparative study on the development of social situation of families in the mattric street in the Neštěmice city part in Ústí and Labem]. Národní centrum sociálních studií, Praha.

Stazsak J (2009) Other/Otherness. In: International Encyclopedia of Human Geography, Oxford.

Sýkora L (2018) Pilotní ověření Metodiky identifikace lokalit rezidenční segregace v obcích ČR [Pilot verification of the Methodology for identification of localities of residential segregation in Czech municipalities]. Univerzita Karlova, Praha.

Vaněk M, Mücke P (2015) Třetí strana trojúhelníku: teorie a praxe orální historie [Third side of the triangle: theory and practice of oral history]. Karolinum, Praha.

Wilson W (2012) The truly disadvantaged: The inner city, the underclass, and public policy. University of Chicago Press, Chicago. 